\title{
Improving Water Use Efficiency and Insect Pest Exclusion on French Bean (Phaseolus vulgaris L.) Using Different Coloured Agronet Covers
}

\author{
Munywoki James Ngelenzi ${ }^{1}$, Ogweno Joshua Otieno ${ }^{1} \&$ Saidi Mwanarusi $^{1}$ \\ ${ }^{1}$ Department of Crops, Horticulture and Soils, Egerton University, Kenya \\ Correspondence: Munywoki James Ngelenzi, Department of Crops, Horticulture and Soils, Egerton University, \\ Kenya. E-mail: jamezngelenzi@gmail.com
}

Received: September 14, 2018

Accepted: November 24, 2018

Online Published: February 15, 2019

doi:10.5539/jas.v11n3p159

URL: https://doi.org/10.5539/jas.v11n3p159

\begin{abstract}
French bean (Phaseolus vulgaris L.) is important in the socio-economic farming systems of East and Central Africa. It is a crop with great potential for addressing food insecurity, income generation and poverty alleviation in the region. Enhanced French bean productivity is hindered by a number of biotic and abiotic constraints as the crop is predominantly grown in open fields. The crop is mostly grown under irrigation and cannot withstand prolonged dry spells. Farmers rely heavily on insecticides to control insect pests. This increases the risk of rejection of their produce due to stringent maximum residue levels (MRLs) in export markets. This study was undertaken in the Horticulture Research and Teaching Field, Egerton University, Kenya to determine the potential of coloured net covers in improving French bean water use efficiency and insect pest exclusion. The experiment was set in a Randomized Complete Block Design (RCBD) with six treatments replicated four times. French bean 'Source' was grown under different coloured nets (white, blue, yellow, grey, and tricolour) and control (open field). Variables measured included; pest population, fresh pod yield, total plant biomass, leaf relative water content (LRWC) and water use efficiency for plant growth (WUE DW). Covering French bean with different coloured net covers reduced the numbers of silverleaf whitefly and black bean aphids. Coloured net covers enhanced crop performance marked by higher fresh pod yield and total plant biomass as well as improved LRWC and WUE DW of the crop. Results of this study present the potential of coloured net covers to be used as part of integrated French bean management programme(s) to reduce insect pest population and pesticide application while enhancing water use efficiency and crop performance under tropical field conditions.
\end{abstract}

Keywords: snap bean, agronets, insect pests, fresh pod yield, total biomass, water use efficiency

\section{Introduction}

French bean (Phaseolus vulgaris L.) is of primary importance as a source of income, nutrition and food security among smallholder farmers in East and Central Africa (ECA) region (Musaana, Ugen-Adrogu, \& Mawejje, 2015). French bean is primarily grown for export with a small quantity consumed in the domestic market (HCD, 2014). In Kenya, the crop accounts for $52 \%$ of the value and $61 \%$ of the volume of total vegetable exports. In 2013, Kenya exported 31,974 metric tons (MT) of French beans representing $42 \%$ increase over the volumes exported in 2012 (HCD, 2014). The crop is exported mainly to the United Kingdom, France, Germany and Netherlands (Kamanu, Chemining'wa, Nderitu, \& Ambuko, 2012). Globally, the yield for French bean ranges between 8 and 10 tonnes per hectare, with high yields of more than 14 tonnes per hectare recorded in China, USA and Latin America (CIAT, 2006). However, the average yield in smallholder farms in ECA is low, ranging between 4 and 8 tonnes per hectare (Kimani, van Rheenen, Mathenge, \& Ndegwa, 2004).

Enhanced French bean productivity is hindered by a number of biotic and abiotic constraints. The major constraints include harsh environmental conditions and heavy infestation by insect pests as the crop is predominantly grown in open fields (Gogo, Saidi, \& Ochieng, 2014). Among the major insect pests affecting French bean production are bean stem maggot (Ophiomyia spp.), bean flower thrips [Megalurothrips sjostedti (Trybom)], western flower thrips [Frankliniella occidentalis (Pergande)], common blossom thrips [Frankliniel laschultzei (Trybom)], bean aphids (Aphis fabae Scopoli), red spider mites (Tetranychus spp.), and whiteflies [Bemisia tabaci Gennadius)] (Nderitu, Wambua, Olubayo, Kasina, \& Waturu, 2007). Farmers rely heavily on 
insecticides to control these insect pests (Nderitu et al., 2007; Gogo et al., 2014). This increases the risk of rejection of their produce should the chemical content exceed the acceptable maximum residue levels (MRLs) in export markets (Odong, 2011). Furthermore reliance on expensive pesticides reduces the profitability of the crop and exposes farmers to toxic pesticides and adversely affects the environment (Musaana et al., 2015). Due to non-compliance by Kenyan small-holder French bean producers with set MRLs, the European Union (EU) subjects Kenyan fresh beans and peas to a 10 percent increase on physical checks at designated ports of entry. This has led to decrease in number of exporters and a decline in exports of the commodity to the EU (GoK, 2012).

The crop is grown almost throughout the year but mostly under irrigation (Monda, Ndegwa, \& Munene, 2003; Nyakundi, Magoma, Ochora, \& Nyende, 2010). In Kenya, irrigation uses over 69 percent of the limited developed water resources (Torori, Mumma, \& Field-Juma, 1995). As a consequence of climate change, it is anticipated that higher temperatures will result in increased evaporation and consumption of natural water for agricultural use (Perry, Steduto, Allen, \& Burt, 2009) on the one hand, while the ever increasing population will on the other hand push up the demand for food. Water for food production must therefore be used more efficiently if a balance between the two scenarios has to be struck (Steduto, Hsiao, \& Fereres, 2007). Technologies that stand to improve on agricultural water use efficiency for plant growth (WUE DW) would therefore be key in alleviating the pressure of the ever-expanding world population on water resources (Zeggaf \& Filali, 2010).

Use of nets has a long history in agricultural production, the documented benefits being physical protection against excessive radiation, insect pests and environmental changes (Shahak, Gussakovsky, Gal, \& Ganelevin, 2004). Nets enable passive control of flying insect pests of crops by creating a physical barrier between the plants and pests (Boiteau \& Vernon, 2004), thus reducing the need for pesticide sprays (Licciardi et al., 2007; Weintraub, 2009). Nets have indirect impact on the behavior of pests by modifying the visual and olfactory signal (Mazzi \& Dorn, 2012) where they mask the crop, thus deterring pests that detect their prey via visual signals (Weintraub \& Berlinger, 2004). Net covers have also been documented to maintain higher soil moisture and relative humidity content within the immediate vicinity of crops (Gogo et al., 2014; Muleke, Saidi, Itulya, Martin, \& Ngouajio, 2014) besides reducing the speed of wind blowing over the plants (Shahak et al., 2004) presenting a potential for lowering crops irrigation requirement while maximizing yields per unit of water supplied. Coloured shade netting not only influences the microclimate to which the plant is exposed to but also exhibit special optical properties to optimize desirable physiological responses of plants (Costa et al., 2010). Coloured shade nets can be used to change red to far-red light ratios that influence plant growth and development (Stamps, 2009).

Evaluations are needed to identify ideal net cover(s) that has a potential for altering the French bean physiological and biochemical processes, metabolite profiles and ultimately growth, development, yield and quality as well as pest exclusion. This study therefore aimed at determining the effects of different coloured agronet covers on insect pest exclusion and improving water use efficiency for growth of French bean.

\section{Materials and Methods}

\subsection{Experimental Site Description}

Two trials (July to October 2015 and November 2015 to February 2016) were conducted at the Horticulture Research and Teaching Field of Egerton University, Njoro, Kenya. The field lies at a latitude of $0^{\circ} 23^{\prime} \mathrm{S}$ and longitude $35^{\circ} 35^{\prime} \mathrm{E}$ in the Lower Highland III Agro Ecological Zone (LH3), at an altitude of $\approx 2238 \mathrm{~m}$ above sea level. The soils are predominantly vitric mollic andosols with a pH of 6.0 to 6.5 (Jaetzold, Schmidt, Hornetz, \& Shisanya, 2006). The site mean temperature and rainfall during the study period are presented in Figure 1. 


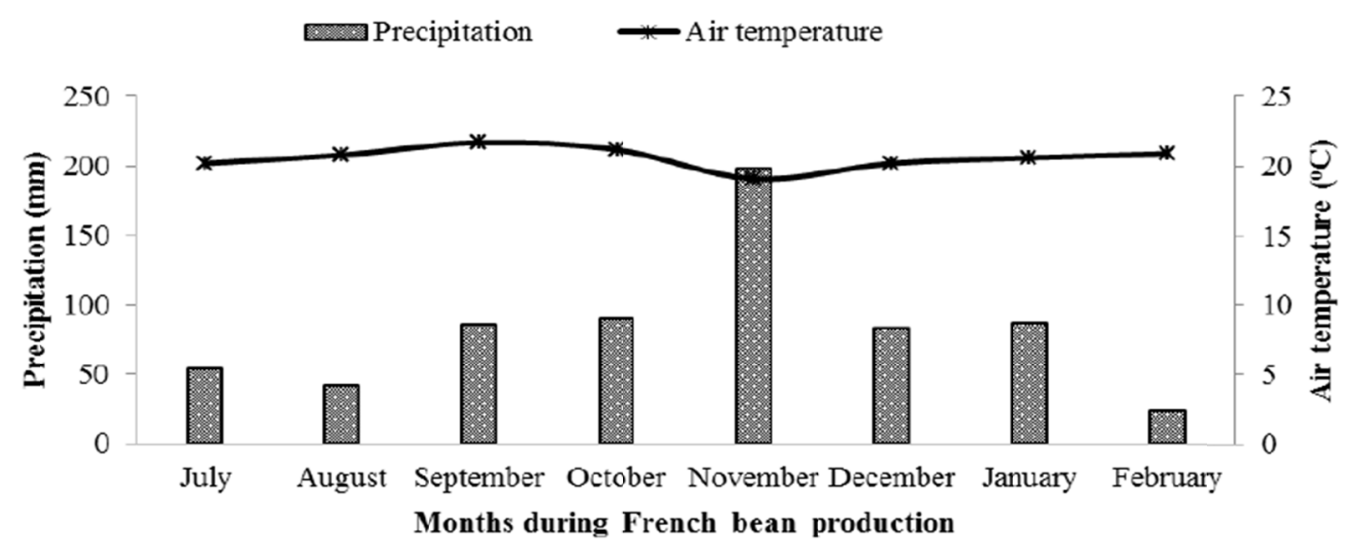

Figure 1. Average monthly air temperature $\left({ }^{\circ} \mathrm{C}\right)$ and precipitation $(\mathrm{mm})$ during French bean production over the two trials (July to October 2015 and November 2015 to February 2016)

Source: Egerton University Engineering Department (2016).

\subsection{Planting Material, Experimental Design and Treatments}

The experiment was laid out in a Randomized Complete Block Design (RCBD) with six treatments replicated four times. French bean cultivar 'Source' (Amiran (K) Ltd., Nairobi, Kenya) was used, grown either under different coloured agronets (white, blue, yellow, grey, and tricolour) or in the open field (control). The tricolour net was predominantly white in colour with blue and yellow stripes. 'Source' is a determinate cultivar and one of the most popular among French bean growers in Kenya. Agronets used were made of ultraviolet protected high-density polyethylene fully recyclable monofilament of 100 denier knitted into a mesh of $0.9 \mathrm{~mm} \times 0.7 \mathrm{~mm}$ average pore size. They were obtained from A to Z Textile Mills Ltd., Arusha, Tanzania.

Each experimental unit measured $3 \mathrm{~m}$ by $2 \mathrm{~m}$ while blocks measured $20.5 \mathrm{~m} \times 2 \mathrm{~m}$. Individual blocks were separated from each other by $1 \mathrm{~m}$ buffer while plots within the blocks were separated by $0.5 \mathrm{~m}$ buffer. Poles 75 $\mathrm{cm}$ long were used to support the agronets in net covered treatments where one pole was placed at each corner and at the center of each plot. The poles were driven $25 \mathrm{~cm}$ into the ground for good anchorage. Agronets measuring $4 \mathrm{~m}$ wide and $5.5 \mathrm{~m}$ long were then mounted on the wooden posts ensuring that each plot was completely covered and that the nets were pegged at each corner to minimize wind interference. Once covered, plots were maintained permanently covered and only opened during routine plant management practices and data collection periods.

\subsection{Land Preparation, Planting and Crop Maintenance}

The field was manually dug using hand hoes and prepared to a fine tilth using rakes. Drills were then made 45 $\mathrm{cm}$ apart giving a total of five rows in each experimental unit. Seeds were sown at a spacing of $10 \mathrm{~cm}$ within the drills. Diammonium phosphate (DAP) was applied at a rate $200 \mathrm{~kg} \mathrm{DAP} \mathrm{ha}^{-1}$ and thoroughly mixed with soil before seeding. Later, calcium ammonium nitrate (CAN) was applied as a top dress at a rate of $200 \mathrm{~kg} \mathrm{CAN} \mathrm{ha}^{-1}$ in two equal splits; at the trifoliate leaf stage and onset of flowering stage (MOARD, 2003). The crop was rain fed with supplemental irrigation given only during periods of extended dry spells. In this case, watering was done using watering cans ensuring that equal amount of water was applied in each experimental unit.

\subsection{Data Collection}

Four plants from the inner rows of each experimental unit were randomly selected for collection of data on insect pest count. Destructive sampling was done to determine plant biomass, leaf relative water content and water use efficiency for plant growth at three different plant growth stages; trifoliate leaf, flowering and podding stages.

\subsubsection{Insect Pest Counts}

The major insect pests counted were black bean aphids (Aphis fabae), silverleaf whitefly (Bemisia tabacci) and bean thrips (Megalurothrips usitatus). The number of black bean aphids at the nymph stage, adult silverleaf whitefly and bean thrips at nymph and adult stage were counted on all the leaves of the selected plants once every two weeks beginning at 21 days after planting (DAP) to first harvest and data obtained was recorded as number per plant (no./plant). Counting of insect pests was done early in the morning before 8.00 am when most pests are still inactive. Hand held lenses were used to magnify the pests for ease of counting. 


\subsubsection{Fresh Pod Yields and Total Biomass}

Pod yields were measured both in terms of numbers and fresh weight per plant. To achieve this, the crop was harvested thrice per week for four weeks removing pods that had attained horticultural maturity stage beginning at 62 DAP. At each harvest, pods harvested from each tagged plant were separately counted and the number of pods obtained recorded and later used to compute the average number of pods per plant (no./plant). The pods were then weighed in grams (gms) using a weighing balance (Advanced Technocracy Inc. Ambala). Obtained weights were recorded in grams per experimental unit and later used to compute average pod weight per plant (gms/plant). Thereafter, a sample was made from the harvest of tagged plants of each experimental unit and 100 grams of fresh pods drawn from the sample for determination of pod dry weight in gms which was later used in the computation of total plant biomass in gms. Total plant biomass was on the other hand determined at three different plant growth stages; trifoliate leaf, flowering and podding stages using four plants from each experimental unit. The plants were dug out recovering most of the roots, cleaned and oven dried at $70{ }^{\circ} \mathrm{C}$ to constant weights and their dry weights determined. The data obtained were used to compute the average total biomass per plant as;

$$
\text { Total Biomass }(\mathrm{g} \text { DW/plant })=\frac{\text { Total Plant Biomass }+ \text { Total Pod Dry Weight }}{4}
$$

Where, Total pod dry weight was computed by multiplying pod dry weight of the 100 grams of fresh pods drawn from the composite sample for biomass determination at each harvest by the total fresh weight obtained for the individual treatments at that harvest then summing up the computed biomass for the individual harvests.

\subsubsection{Leaf Relative Water Content and Water Use Efficiency for Plant Growth}

Leaf relative water content (LRWC) and water use efficiency for plant growth (WUE DW) were also determined at the three plant growth stages; trifoliate leaf, flowering and podding stages. LRWC is the water content of a given tissue at a given time as related to the water content at full turgor hence a useful indicator of the state of water balance of a plant (González \& González-Vilar, 2001). Leaf samples used for LRWC determination were taken from each experimental unit between 6:30 and 7:30 am, sealed in plastic bags, and taken to the laboratory. The youngest fully expanded leaves were used. In the laboratory, LRWC was determined according to the method described by Barrs and Weatherley (1962), based on the following equation:

$$
\mathrm{LRWC}=[(\mathrm{FW}-\mathrm{DW}) /(\mathrm{SW}-\mathrm{DW})] \times 100
$$

Where, FW is leaf fresh weight, DW is dry weight of leaves after drying at $70^{\circ} \mathrm{C}$ until a constant weight is achieved, and SW is the turgid weight of leaves after soaking in water for $4 \mathrm{~h}$ at room temperature. LRWC is a ratio of the amount of water in the leaf tissue at sampling to that present when fully turgid.

Water use efficiency for plant growth (WUE DW) was calculated as the ratio of total plant biomass (g DW) to leaf water content ( $\left.\mathrm{mL} \mathrm{g}^{-1} \mathrm{DW}\right)$ as described by (Krouma, 2010) where;

$$
\text { WUE for Plant Growth }=\frac{\text { Total Plant Biomass }(\mathrm{g} \mathrm{DW})}{\text { Leaf Water Content }\left(\mathrm{mL} \mathrm{g}^{-1} \mathrm{DW}\right)}
$$

\subsection{Data Analysis}

The Proc univariate procedure of SAS (Version 9.1; SAS Institute, Cary, NC) was used to check for normality of the data before analysis. Data were then subjected to analysis of variance (ANOVA) using the GLM procedure of SAS at $\mathrm{P} \leq 0.05$. Data were analyzed using the basic RCBD statistical model:

$$
\mathrm{Y}_{\mathrm{ij}}=\mu+\beta_{\mathrm{i}}+\alpha_{\mathrm{j}}+\varepsilon_{\mathrm{ij}}
$$

Where, $Y_{i j}$ is the French bean response, $\mu$ is the overall mean, $\beta_{i}$ is the $i^{\text {th }}$ blocking effect, $\alpha_{j}$ is the effect due to the $\mathrm{j}^{\text {th }}$ treatment, and $\varepsilon_{\mathrm{ij}}$ is the random error term. Means for significant treatments at $\mathrm{F}$ test were separated using Tukey's honestly significant difference (THSD) test at $\mathrm{P} \leq 0.05$.

\section{Results}

\subsection{Effects of Colour of Agronet Cover on Insect Pest Population on French Bean}

Aphids, silverleaf whitefly and thrips were the major insect pests identified during this study.

Aphids: Growing French bean under the different coloured agronet covers reduced the number of aphid population on the crop compared to open field production (Table 1). Regardless of the colour of agronet cover used, lower aphid population was recorded under net covered treatments compared to under open field production. During early sampling dates up to 35 DAP aphid population was generally lower on all treatments. Beyond 35 DAP, a marked increase in aphid population was observed with the highest increase recorded under the control treatment and the lowest increase under the yellow net cover. Plants grown under the yellow and 
tricolour net covers had significantly lower aphid population compared with the control plants by 49 and 63 DAP while plants covered with the white net had significantly lower aphid population than the control plants by 63 DAP. Aphid population also remained lower under all other net covers compared to the control treatment but with no statistical difference observed. Among the net covers, the highest aphid population was recorded under the grey net cover while the lowest was under the yellow net. The number of aphids observed on plants under the white net cover tended to be lower than those under the blue net cover but slightly higher than those under the tricolour net cover in most data collection dates.

Table 1. Effects of colour of agronet cover on insect pest population (no./plant) during French bean production

\begin{tabular}{|c|c|c|c|c|}
\hline \multirow{2}{*}{ Treatment } & \multicolumn{4}{|c|}{ Days after Planting } \\
\hline & 21 & 35 & 49 & 63 \\
\hline \multicolumn{5}{|c|}{ Aphids (no./plant) } \\
\hline White & 0 & 3.94 & $9.44 \mathrm{ab}$ & $31.50 \mathrm{ab}$ \\
\hline Tricolour & 0 & 0.69 & $4.50 \mathrm{~b}$ & $16.06 \mathrm{~b}$ \\
\hline Grey & 1.13 & 14 & $36.31 \mathrm{ab}$ & $107.19 \mathrm{a}$ \\
\hline Yellow & 0 & 0 & $1.94 b$ & $5.19 b$ \\
\hline Blue & 0 & 4.38 & $19.63 \mathrm{ab}$ & $68.06 \mathrm{ab}$ \\
\hline Control & 1.69 & 16.88 & $54.00 \mathrm{a}$ & $120.56 \mathrm{a}$ \\
\hline \multicolumn{5}{|c|}{ Whiteflies (no./plant) } \\
\hline White & 1.17 & $0.61 b$ & $0.36 b$ & $8.27 b$ \\
\hline Tricolour & 1.08 & $2.53 b$ & $0.80 \mathrm{~b}$ & $6.56 b$ \\
\hline Grey & 1.03 & $3.80 \mathrm{~b}$ & $1.33 b$ & $7.50 \mathrm{~b}$ \\
\hline Yellow & 0.42 & $0.38 \mathrm{~b}$ & $0.20 \mathrm{~b}$ & $3.33 b$ \\
\hline Blue & 1.22 & $1.36 \mathrm{~b}$ & $1.67 \mathrm{~b}$ & $8.41 \mathrm{~b}$ \\
\hline Control & 1.95 & $17.91 \mathrm{a}$ & $5.38 \mathrm{a}$ & $19.39 \mathrm{a}$ \\
\hline \multicolumn{5}{|c|}{ Thrips (no./plant) } \\
\hline White & $0.60 \mathrm{a}$ & $16.88 \mathrm{a}$ & $47.13 \mathrm{ab}$ & $84.09 \mathrm{a}$ \\
\hline Tricolour & $0.72 \mathrm{a}$ & $7.14 \mathrm{ab}$ & $74.23 \mathrm{a}$ & $97.47 \mathrm{a}$ \\
\hline Grey & $0.13 \mathrm{ab}$ & 7.64ab & $18.69 b c$ & $32.94 b$ \\
\hline Yellow & $0.58 \mathrm{ab}$ & $4.52 b c$ & $8.27 \mathrm{~cd}$ & $13.39 b c$ \\
\hline Blue & $0.09 \mathrm{ab}$ & $5.36 \mathrm{bc}$ & $14.69 \mathrm{bcd}$ & $29.78 b$ \\
\hline Control & $0.00 \mathrm{~b}$ & $0.55 \mathrm{c}$ & $1.89 \mathrm{~d}$ & $2.50 \mathrm{c}$ \\
\hline
\end{tabular}

Note. ${ }^{*}$ Means followed by the same or no letters within a column and a parameter are not significantly different according to Tukey's Honestly Significant Difference Test at $\mathrm{P} \leq 0.05$. Data were subjected to square root transformation before analysis but values presented are original means.

Silverleaf Whitefly: Similar to aphid population, whitefly population was consistently lower on French bean plants grown under net covers than the control plants on all data collection dates. The lowest population of whitefly was also recorded under the yellow net cover while the highest population was under open field treatment. Among the net covered treatments, the highest population of whitefly was mostly observed on plants grown under blue net cover with intermediate populations recorded under the white, tricolour and grey net covers with no statistically significant differences among them within the different data collection dates.

Thrips: Contrary to aphid and whitefly population, growing French bean under the different coloured agronet covers resulted in an increase in the number of thrips on the French bean crop. Thrips population was generally lowest on plants grown under the control treatment in most data collection dates. Plants under white and tricolour net covers registered significantly higher thrip numbers than control plants in all data collection dates. Among the net covered treatments, the lowest thrips population was observed on plants grown under the yellow net cover at most data collection dates. Thrips population recorded for plants grown under the yellow net cover tended to be slightly higher than that of control plants with the difference not being significant in all data collection dates. Among the other treatments, thrips population was slightly higher under the grey net cover than under the blue net cover and highest under the white and tricolour net covers. 


\subsection{Effects of Colour of Agronet Cover on Fresh Pod Yield and Plant Biomass}

\subsubsection{Pod Numbers and Fresh Pod Weight}

Growing French bean under the different coloured agronet covers had a positive influence on the number of pods produced by individual plants. Generally higher pod numbers were recorded for plants grown under the different coloured agronet covers compared to those of the control treatment (Figure 2). Among the net covers, plants covered with the blue net cover registered the lowest number of pods while the highest number of pods was recorded under the white net cover. Pod numbers for plants grown under yellow, tricolour and grey net covers were not statistically different from those obtained under both the white and blue net covers. Similar to pod numbers, French bean fresh pod weight was also higher under agronet covers compared to the control treatment (Figure 2). Among the different net covers, pod weight was highest under the white net cover then under yellow net covers, followed by tricolour then grey net covers and lowest under the blue net covers.

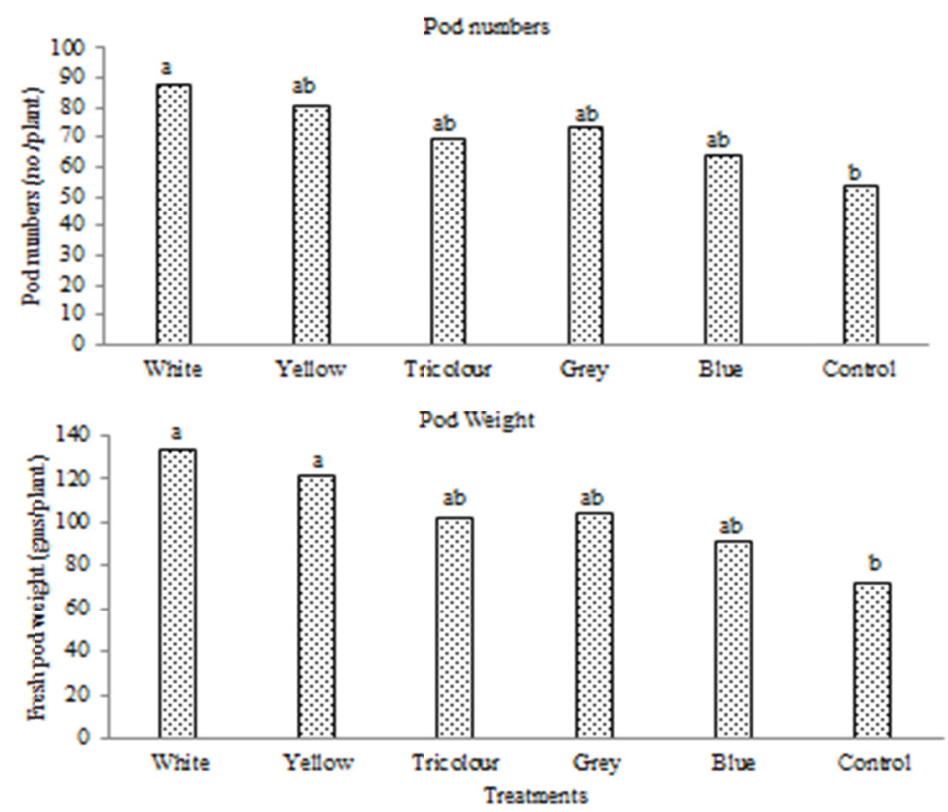

Figure 2. Effects of colour of agronet cover on French bean fresh pod yield. Data points within the same parameter followed by the same letter are not significantly different according to Tukey's Honestly Significant

Difference Test at $\mathrm{P} \leq 0.05$. Data were subjected to square root transformation before analysis but values presented are original means

\subsubsection{Plant Biomass}

Growing French bean plants under different coloured agronet covers also influenced the plant biomass at the different plant growth stages. Biomass was generally higher for plants grown under net covers compared to those grown in the open field (Figure 3). At the trifoliate stage, French bean plants grown under the tricolour net yielded the highest plant biomass which was not statistically different from that recorded for plants grown under the white and grey net covers. Plants grown under the yellow net cover yielded intermediate biomass while the blue net cover yielded the lowest biomass among the net covered treatments. Overall, total plant biomass was lowest under the control treatments. At the flowering stage, all net covered treatments yielded significantly higher total plant biomass compared to the control treatment plants with no statistical difference noted between total biomass of the different net cover treatments. At podding stage, plants grown under the white net cover registered the highest total plant biomass with the lowest biomass obtained under the control treatment. Among the other treatments, total biomass was in descending order; yellow, tricolour, grey and blue net covers. When total biomass at podding stage was partitioned into shoot and pod biomass (Figure 3), the highest shoot and pod biomass was also obtained under the white net cover while the lowest was under the control treatment. Shoot and pod biomass obtained for the white net cover treatment were significantly higher than those obtained for the blue net cover and control treatments but not statistically different from those recorded for the yellow, tricolor and grey net covers. 


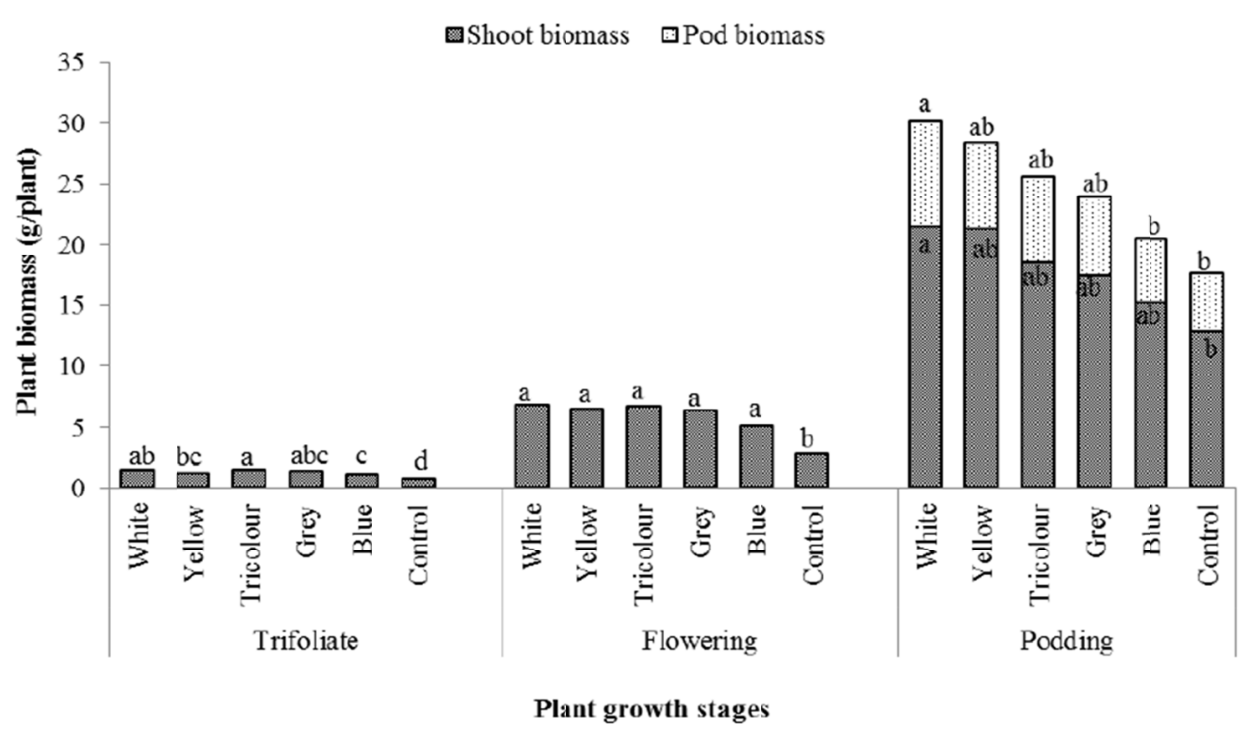

Figure 3. Effects of colour of agronet cover on French bean plant biomass (gms/plant). Data points within the same growth stage followed by the same letter in a letter series are not significantly different according to Tukey's Honestly Significant Difference Test at $\mathrm{P} \leq 0.05$. Data were subjected to square root transformation before analysis but values presented are original means

\subsection{Effects of Colour of Agronet Cover on Leaf Relative Water Content and Water Use Efficiency for Plant Growth of French Bean}

Growing French bean under the different coloured agronet covers improved plant LRWC and WUE DW compared to open field production (Table 2). Regardless of the colour of agronet cover used, higher percent LRWC was recorded under net covers compared to open field production in all sampling dates. Plants grown under blue net cover registered highest percent LRWC while those under open field condition had the lowest LRWC at all sampling dates. At the trifoliate stage, percentage LRWC for plants grown under the blue net cover was significantly higher than for those grown under white and grey net covers. LRWC for this treatment was not statistically different from that recorded for leaves of plants grown under the yellow and tricolour net covers at this stage of plant growth. At flowering stage, the highest LRWC was also obtained in leaves of plants grown under the blue net cover which was not statistically different from that of leaves of plants grown under the yellow, tricolour and grey net. Plants grown under the white net cover also had leaves with a higher LRWC than those of control plants although the difference was not significant. Similarly, leaves of plants grown under the blue net cover registered the highest LRWC at podding stage with the lowest LRWC obtained for plants under the control treatment. Among the other treatments, LRWC obtained for plants under the yellow, grey and white net covers were not any significantly different from that recorded for plants under the blue net cover. Leaves of plants grown under the tricolour net recorded significantly lower LRWC compared to those of other net covers. LRWC of this treatment however remained significantly higher than that of the control treatment. 
Table 1. Effects of colour of agronet cover on French bean leaf relative water content (\%) and water use efficiency for plant growth (WUE DW) during French bean production

\begin{tabular}{llll}
\hline \multirow{2}{*}{ Treatment } & \multicolumn{2}{c}{ Plant Growth Stages } \\
\cline { 2 - 4 } Leaf relative water content (\%) & Trifoliate & Flowering & Podding \\
White & & & \\
Tricolour & $90.06 \mathrm{~b}$ & $88.51 \mathrm{ab}$ & $85.59 \mathrm{ab}$ \\
Grey & $92.39 \mathrm{ab}$ & $89.21 \mathrm{a}$ & $84.17 \mathrm{~b}$ \\
Yellow & $91.63 \mathrm{~b}$ & $90.31 \mathrm{a}$ & $86.39 \mathrm{ab}$ \\
Blue & $92.85 \mathrm{ab}$ & $90.88 \mathrm{a}$ & $86.72 \mathrm{ab}$ \\
Control & $94.45 \mathrm{a}$ & $91.59 \mathrm{a}$ & $87.71 \mathrm{a}$ \\
Water use efficiency for plant growth $($ WUE DW) & $86.24 \mathrm{~b}$ & $80.64 \mathrm{c}$ \\
White & $0.21 \mathrm{ab}$ & & \\
Tricolour & $0.22 \mathrm{a}$ & $1.25 \mathrm{a}$ & $8.17 \mathrm{a}$ \\
Grey & $0.19 \mathrm{ab}$ & $1.20 \mathrm{a}$ & $6.85 \mathrm{ab}$ \\
Yellow & $0.18 \mathrm{bc}$ & $1.09 \mathrm{a}$ & $6.75 \mathrm{ab}$ \\
Blue & $0.15 \mathrm{~cd}$ & $1.10 \mathrm{a}$ & $8.38 \mathrm{a}$ \\
Control & $0.12 \mathrm{~d}$ & $0.89 \mathrm{a}$ & $5.49 \mathrm{ab}$ \\
\hline
\end{tabular}

Note. * Means followed by the same letter within a column and a parameter are not significantly different according to Tukey's Honestly Significant Difference Test at $\mathrm{P} \leq 0.05$. Data for LRWC were subjected to arcsine transformation before analysis but values presented are original means.

WUE DW was also influenced by the use of the different coloured agronet covers. French bean plants grown under the net covers had higher WUE DW compared to control plants. At the trifoliate stage, WUE DW for plants grown under the white and tricolour net covers was significantly higher than for those plants grown under yellow and blue net covers. At the flowering stage, all net covered treatments recorded significantly higher WUE DW compared to the control treatment plants with no statistical difference noted among WUE DW of the different net covered treatments. At podding stage, plants grown under the net covered treatments recorded higher WUE DW than those of control treatment. WUE DW for plants grown under white and yellow net covers was significantly different than those of control plants. Plants grown under the tricolour, grey and blue net covers registered higher WUE DW than those of control plants although the difference was not significant. However, plants grown under the tricolour net cover recorded slightly higher WUE DW than that of grey and blue net covered plants.

\section{Discussion}

In the current study, growing French bean under different coloured agronet covers reduced population of silverleaf whitefly and black bean aphid and increased the number of thrips compared with the control treatment. Physical barrier provided by the net covers disrupts feeding and mating habits of many insect pests, thereby lowering their population (Martin, Assogba-Komlan, Houndete, Hougard, \& Chandre, 2006). Light spectrum plays an important role in aspects of insect pest behavior including navigation and orientation (Antignus \& Ben-Yakir, 2004). Flying aphids and whiteflies are repelled by a high intensity of reflected light (Summers, Mitchell, \& Stapleton, 2004; Simmons, Kousik, \& Levi, 2010). Penetration of, and infestation by thrips, aphids and whiteflies is differentially affected by photoselective nets (Shahak, Ratner, Zur, Offir, \& Matan, 2009) with a potential reduction in population of aphids and whiteflies on plants under net covers attributed to light scattering and diffusion by the coloured nets (Shahak et al., 2004). Lower aphid and whitefly population obtained under the different coloured agronet cover treatments compared to open field production in the current study could thus be attributed to such effects of net covers on pest behavior which might have affected the ability of the aphids and whiteflies to find their host. Studies by Ben-Yakir, Hadar, Offir, Chen, and Tregerman (2008) and Shahak et al. (2009) reported that yellow shading nets have the ability to protect crops from aphids and whiteflies. This argument corroborates the findings of the current study where French beans grown under yellow agronet cover recorded the lowest silverleaf whitefly and aphid population compared to all other treatments.

In the current study, French bean plants grown under different coloured agronet covers recorded higher thrips population than control treatment. Among the net covered treatments, the lowest thrips population was recorded on French bean grown under the yellow agronet cover. Thrips numbers is significantly affected by weather 
variables including rainfall, temperature, relative humidity and wind (Ananthakrishnan, 1993; Legutowska, 1997). Reduced thrips population recorded on plants grown under the control treatment in the current study could partly have been as a result of higher wind speed blowing over the plants as the net covers tend to reduce the speed of wind (Shahak et al., 2004). Lower thrips population in the current study under the yellow agronet cover could be a result of higher relative humidity and lower average air temperatures. Relatively high temperatures and dry conditions have been associated with increase in thrips population, while high relative humidity and rainfall reduce thrips population and vice versa (Hamdy \& Salem, 1994).

French bean grown under the different coloured net covers also produced more pods and had higher pod weight and total plant biomass compared with the control treatment. Temperature and moisture are important in photosynthesis during which dry matter is produced and transported to the sink (Berry \& Bjorkman, 1980) as well as in the general physiological development of any given crop (Saidi, Gogo, Itulya, Martin, \& Ngaouajio, 2013; Gogo et al., 2014). Screens reduce the mixing of outside and inside air, hence effectively reducing loss of heat to the surrounding atmosphere, which leads to a temperature increase (Tanny, Cohen, Grava, Noar, \& Lukyanov, 2008). Colour shade nets prevent excess sunlight and retain soil moisture for proper plant growth and productivity (Ilić, Milenković, Đurovka, \& Kapoulas, 2011). The higher fresh pod yield and total biomass recorded under agronet covers in the current study could be as a result of high air temperatures and moisture conditions under these net covers leading to the better crop performance. Sucking pests are also known to directly affect crop performance through sucking of plant sap or indirectly through transmission of viral diseases (Gogo et al., 2014). It is therefore possible that the higher fresh pod yield and total plant biomass observed under coloured net covers in the current study could partly have been a result of the reduction in silverleaf whitefly and black bean aphid under these treatments. Better performance observed on plants under net covers could also be attributed to improved light compensation under net covers as a result of favorable microclimatic conditions (Nangare, Singh, Meena, Bhushan, \& Bhatnagar, 2015).

In the current study, LRWC was higher under the different coloured agronet covers than the control treatment. Net covers have been shown to maintain higher soil moisture and relative humidity content within the immediate vicinity of crops (Gogo et al., 2014; Muleke et al., 2014) besides reducing the speed of wind speed blowing over the plants (Shahak et al., 2004). According to Allen (1975), net covers produce a humid blanket, which contribute to decreasing environmental evaporative demand. High LRWC recorded for plants under net covers in the current study could therefore have been as a result of the high soil moisture and relative humidity and reduced wind speed under the net covers. This could possibly have contributed to reduced transpiration losses as a result of thick moist boundary layer close to the leaf surface which could in turn have increased the leaf water potential leading to better plant turgor under nets compared to open field production. The higher values of LRWC observed for plants under yellow and blue net covers in the current study could be attributed to the even higher relative humidity and soil moisture contents recorded under these net covers. The lower values of LRWC of leaves observed from open field grown plants compared to net covered plants could be as a result of higher evaporative demand under open field. In this sense, leaves for plants grown under coloured net covers are more water conserving than those of open field grown plants.

WUE DW was also higher under the different coloured agronet covers than under the control treatment in the current study. WUE DW for plant growth can be increased by enhancing crop yield per unit of water used (Richards, Rebetzke, Condon, \& van Herwaarden, 2002). Crop production can be sustained by interventions able to increase WUE DW in order to limit yield penalties under a changing climate of increased temperatures and decreased precipitation (Parry, Flexas, \& Medrano, 2005). WUE DW is generally used to express the ratio of total dry matter production to evapotranspiration and is influenced by a variety of factors such as crop type, atmospheric environment, cultivation practices and soil conditions (Liu, Hunsaker, Li, Xie, \& Wall, 2002). Hatfield, Sauer, and Prueger (2001) proposed that practices which increase water availability would lead to improved WUE DW. The high WUE DW for plant growth observed in net grown plants in the current study could therefore have been as a result of high leaf water potential favoured by high relative humidity and soil moisture and better light distribution as a result of light scattering which favours photosynthesis and metabolites translocation. High atmospheric humidity enhances atmospheric stability suggesting a potential reduction of atmospheric water demand thereby reducing evapotranspiration and increasing leaf water potential. Coloured agronets block excess sunlight and maintain higher soil moisture and relative humidity content for proper plant growth and productivity (Ilic et al., 2011). Growing French bean plant under white and yellow net covers in the current study resulted to higher values of WUE DW which could be attributed to the increased plant biomass production and higher yield observed under these treatments. Similarly, a number of studies in apricot (Nicolás, Torrecillas, Dell, \& Alarcón, 2005) and citrus species (Alarcón, Ortuno, Nicolás, Navarro, \& Torrecillas, 2006) 
using shade nets have reported that WUE DW can be increased by reducing excessive irradiance. Similarly, Gent (2008) reported decreased crop water use and increased water use efficiency with shading in greenhouse-grown tomato. Investigation by FAO (1991) also revealed considerably lower crop water requirements in greenhouses than in open fields for similar levels of production which was attributed to the much lower evapotranspiration inside greenhouses.

\section{Conclusions and Recommendations}

Results of the present study reveal that growing of French bean under coloured agronet covers reduces insect pest populations and enhances water use efficiency and crop performance. Based on the findings of this study, white or yellow net cover is recommended for use in French bean production to improve fresh pod yield and water use efficiency and the use of yellow net cover to protect French bean crop against silverleaf whitefly and black bean aphids in regions with similar climatic conditions to those of this site. We also recommend cost-effectiveness studies of French bean production under net covers and open field be done to establish the economic benefits of growing French bean under net covers.

\section{Acknowledgements}

This is part of Master of Science in Horticulture project by James N. Munywoki. The study was in part made possible by support of the National Research Fund of Kenya under Award No. NACOSTI/RCD/ST\&I/7TH CALL/MSc/107. Thanks to the Departments of Crops, Horticulture and Soils of Egerton University-Kenya for hosting the study.

\section{Reference}

Alarcón, J. J., Ortuno, M. F., Nicolás, E., Navarro, A., \& Torrecillas, A. (2006). Improving water-use efficiency of young lemon trees by shading with aluminised-plastic nets. Agricultural Water Management, 82(3), 387-398. https://doi.org/10.1016/j.agwat.2005.08.003

Allen, L. H. (1975). Shade-cloth microclimate of Soybeans 1. Agronomy Journal, 67(2), 175-181. https://doi.org/ 10.2134/agronj1975.00021962006700020001x

Ananthakrishnan, T. N. (1993). Bionomics of thrips. Annual Review of Entomology, 38(1), 71-92. https://doi.org/ 10.1146/annurev.en.38.010193.000443

Antignus, Y., \& Ben-Yakir, D. (2004). Ultraviolet absorbing barriers, an efficient integrated pest management tool to protect greenhouses from insects and virus diseases. In A. R Horowitz, \& I. Ishaaya (Eds.), Insect Pest Management-Field and Protected Crops (pp. 319-335). Springer Publishers, Berlin Heidelberg. https://doi.org/10.1007/978-3-662-07913-3_13

Barrs, H. D., \& Weatherley, P. E. (1962). A re-examination of the relative turgidity technique for estimating water deficits in leaves. Australian Journal of Biological Sciences, 15(3), 413-428. https://doi.org/10.1071/ BI9620413

Ben-Yakir, D., Hadar, M. D., Offir, Y., Chen, M., \& Tregerman, M. (2008). Protecting crops from pests using OptiNet ${ }^{\circledR}$ screens and ChromatiNet ${ }^{\circledR}$ shading nets. Acta Horticulturae, 770, 205-212. https://doi.org/ 10.17660/ActaHortic.2008.770.24

Berry, J., \& Bjorkman, O. (1980). Photosynthetic response and adaptation to temperature in higher plants. Annual Review of Plant Physiology, 31, 491-543. https://doi.org/10.1146/annurev.pp.31.060180.002423

Boiteau, G., \& Vernon, R. S. (2004). Physical barriers for the control of insect pests. In A. R. Horowitz, \& I. Ishaaya (Eds.), Insect pest management (pp. 224-247). Springer, Berlin.

CIAT (Center for International Agricultural Technology). (2006). Beans (Phaseolus vulgaris L.) for Income Generation by Small Scale Farmers in East Africa. Horticultural Insights, 2(31), 69.

Costa, L. C. D. B., Pinto, J. E. B. P., Castro, E. M. D., Alves, E., Bertolucci, S. K. V., \& Rosal, L. F. (2010). Effects of coloured shade netting on the vegetative development and leaf structure of Ocimum selloi. Bragantia, 69(2), 349-359. https://doi.org/10.1590/S0006-87052010000200012

FAO (Food and Agriculture Organization of the United Nations). (1991). Protected cultivation in the Mediterranean climate. Plant Protection Paper 90. Rome, Italy.

Gent, M. P. (2008). Density and duration of shade affect water and nutrient use in greenhouse tomato. Journal of the American Society for Horticultural Science, 133(4), 619-627. 
Gogo, E. O., Saidi, M., \& Ochieng, J. M. (2014). Microclimate Modification and Insect Pest Exclusion Using Agronet Improve Pod Yield and Quality of French Bean. HortScience, 49(10), 1298-1304.

Gonzalez, L., \& Gonzalez-Vilar, M. (2001). Determination of relative water content. In M. J. Reigosa (Ed.), Roger handbook of plant ecophysiology techniques (pp. 207-212). Kluwer Academic Publishers, New York.

Hamdy, M. K., \& Salem, M. (1994). The effect of plantation dates of onion, temperature and relative humidity on the population density of the onion thrips, in Egypt. Annals of Agricultural Science, 39(1), 417-424.

Hatfield, J. L., Sauer, T. J., \& Prueger, J. H. (2001). Managing soils to achieve greater water use efficiency: A Review. Agronomy Journal, 93(2), 271-280. https://doi.org/10.2134/agronj2001.932271x

HCD (Horticultural Crops Directorate). (2014). French beans (Phaseolus vulgaris). Retrieved from http://www.hcda.or.ke/tech/fruit details

Ilić, Z., Milenković, L., Đurovka, M., \& Kapoulas, N. (2011). The effect of color shade nets on the greenhouse climate and pepper yield. Proceedings of $46^{\text {th }}$ Croatian and $6^{\text {th }}$ International Symposium on Agriculture, Opatija Croatia (pp. 529-532).

Jaetzold, R., Schmidt, H., Hornetz, B., \& Shisanya, C. A. (2006). Farm Management Handbook of Kenya. Natural Conditions and Farm Information (Vol. 11/C, 2nd ed.). Ministry of Agriculture/GTZ, Nairobi, Kenya.

Kamanu, J. K., Chemining'wa, G. N., Nderitu, J. H., \& Ambuko, J. (2012). Growth, yield and quality response of snap bean (Phaseolus vulgaris L.) plants to different inorganic fertilizers applications in central Kenya. Journal of Applied Biosciences, 55, 3944-3952.

Kimani, P. M., van Rheenen, H., Mathenge, P., \& Ndegwa, A. (2004). Breeding snap bean for smallholder production in East and Central Africa. Bean Improvement for the Tropics, Annual Report 2004 (pp.49-51). CIAT, Cali, Colombia.

Krouma, A. (2010). Plant water relations and photosynthetic activity in three Tunisian chickpea (Cicer arietinum L.) genotypes subjected to drought. Turkish Journal of Agriculture and Forestry, 34(3), 257-264.

Legutowska, H. (1997). The occurrence of onion thrips (Thrips tabaci Lindeman) on leek plants. Progress in Plant Protection, 37(2), 57-60.

Licciardi, S., Assogba-Komlan, F., Sidick, I., Chandre, F., Hougard, J. M., \& Martin, T. (2007). A temporary tunnel screen as an eco-friendly method for small-scale farmers to protect cabbage crops in Benin. International Journal of Tropical Insect Science, 27(3-4), 152-158. https://doi.org/10.1017/S174275840 7883184

Liu, W. Z., Hunsaker, D. J., Li, Y. S., Xie, X. Q., \& Wall, G. W. (2002). Interrelations of yield, evapotranspiration, and water use efficiency from marginal analysis of water production functions. Agricultural Water Management, 56(2), 143-151. https://doi.org/10.1016/S0378-3774(02)00011-2

Martin, T., Assogba-Komlan, F., Houndete, T., Hougard, J. M., \& Chandre, F. (2006). Efficacy of mosquito netting for sustainable small holders' cabbage production in Africa. Journal of Economic Entomology, 99(2), 450-454. https://doi.org/10.1093/jee/99.2.450

Mazzi, D., \& Dorn, S. (2012). Movement of insect pests in agricultural landscapes. Annals of Applied Biology, 160(2), 97-113. https://doi.org/10.1111/j.1744-7348.2012.00533.x

MOARD (Ministry of Agriculture and Rural Development). (2003). Fruits and vegetable hand book (p. 250). Agricultural Information Resource Centre, Nairobi, Kenya.

Monda, E. O., Ndegwa, A., \& Munene, S. (2003). French beans production constraints in Kenya. African Crop Science Conference Proceedings, 6, 683-687.

Muleke, E. M., Saidi, M., Itulya, F. M., Martin, T., \& Ngouajio, M. (2014). Enhancing cabbage (Brassica oleraceae Var capitata) yields and quality through microclimate modification and physiological improvement using agronet covers. Sustainable Agriculture Research, 3(2), 24-34. https://doi.org/10.5539/ sar.v3n2p24

Musaana, S., Ugen-Adrogu, M., \& Mawejje, D. (2015).Yield stability of some bush snap bean genotypes in Uganda. Direct Research Journal of Agricultural and Food Science, 3(4), 74-82. 
Nangare, D. D., Singh, J., Meena, V. S., Bhushan, B., \& Bhatnagar, P. R. (2015). Effect of green shade nets on yield and quality of tomato (Lycopersicon esculentum Mill) in semi-arid region of Punjab. Asian Journal of Advances in Basic and Applied Science, 1(1), 1-8.

Nderitu, J. H., Wambua, E. M., Olubayo, F., Kasina, M. J., \& Waturu, C. N. (2007) Management of thrips (Thysanoptera: Thripidae) infestation on French beans (Phaseolus vulgaris L.) in Kenya by combination of insecticides and varietal resistance. Journal of Entomology, 4(6), 469-473. https://doi.org/10.3923/je.2007. 469.473

Nicolás, E., Torrecillas, A., Dell Amico, J., \& Alarcón, J. J. (2005). Sap flow, gas exchange, and hydraulic conductance of young apricot trees growing under a shading net and different water supplies. Journal of Plant Physiology, 162(4), 439-447. https://doi.org/10.1016/j.jplph.2004.05.014

Nyakundi, W. O., Magoma, G., Ochora, J., \& Nyende, A. B. (2010). A survey of pesticide use and application patterns among farmers: a case study from selected horticultural farms. Proceedings of the $12^{\text {th }}$ KARI Biennial Scientific conference (pp. 618-630). Rift valley and central provinces, Kenya.

Odong, M. (2011). Regulation and use of agrochemicals and the effects of maximum residue levels on snap bean production for domestic, regional and international markets. In M. Katafire, M. Ugen, \& M. Mcharo (Eds.), Snap bean commodity value chain. Proceedings of the Regional Stakeholders' Workshop, 9-10 December 2009, Imperial Resort Beach Hotel, Entebbe, Uganda (pp. 65-70). ASARECA, Entebbe, Uganda.

Parry, M. A. J., Flexas, J., \& Medrano, H. (2005). Prospects for crop production under drought: Research priorities and future directions. Annals of Applied Biology, 147(3), 211-226. https://doi.org/10.1111/ j.1744-7348.2005.00032.x

Perry, C., Steduto, P., Allen, R. G., \& Burt, C. M. (2009).Increasing productivity in irrigated agriculture: Agronomic constraints and hydrological realities. Agricultural Water Management, 96(11), 1517-1524. https://doi.org/10.1016/j.agwat.2009.05.005

Richards, R. A., Rebetzke, G. J., Condon, A. G., \& van Herwaarden, A. F. (2002). Breeding opportunities for increasing the efficiency of water use and crop yield in temperate cereals. Crop Science, 42(1), 111-121. https://doi.org/10.2135/cropsci2002.1110

Saidi, M., Gogo, E. O., Itulya, F. M., Martin, T., \& Ngaouajio, M. (2013). Microclimate Modification using Eco-friendly Nets and Floating Row Covers Improves Tomato [Lycopersicon esculentum (Mill)] Yield and Quality for Small Holder Farmers in East Africa. Agricultural Sciences, 4, 577-584. https://doi.org/10.4236/ as.2013.411078

Shahak, Y., Gussakovsky, E. E., Gal, E., \& Ganelevin, R. (2004). ColorNets: Crop protection and light-quality manipulation in one technology. Acta Horticulturae, 659, 143-151. https://doi.org/10.17660/ActaHortic. 2004.659.17

Shahak, Y., Ratner, K., Zur, N., Offir, Y., \& Matan, E. (2009). Photoselective netting: An emerging approach in protected agriculture. Acta Horticulturae, 807, 79-84. https://doi.org/10.17660/ActaHortic.2009.807.7

Simmons, A. M., Kousik, C. S., \& Levi, A. (2010). Combining reflective mulch and host plant resistance for sweetpotato whitefly (Hemiptera: Aleyrodidae) management in watermelon. Crop Protection, 29(8), 898-902. https://doi.org/10.1016/j.cropro.2010.04.003

Stamps, R. H. (2009). Use of colored shade netting in horticulture. HortScience, 44(2), 239-241.

Steduto, P., Hsiao, T. C., \& Fereres, E. (2007). The conservative behavior of biomass water productivity. Irrigation Science, 25(3), 189-207. https://doi.org/10.1007/s00271-007-0064-1

Summers, C. G., Mitchell, J. P., \& Stapleton, J. J. (2004). Management of aphid-borne viruses and Bemisia argentifolii (Homoptera: Aleyrodidae) in zucchini squash by using UV reflective plastic and wheat straw mulches. Environmental Entomology, 339(5), 1447-1457. https://doi.org/10.1603/0046-225X-33.5.1447

Tanny, J., Cohen, S., Grava, A., Noar, A., \& Lukyanov, V. (2008). The effect of shading screens on microclimate of apple orchards. Chilean Journal, 4, 347-359. https://doi.org/10.17660/ActaHortic.2009.807.11

Torori, C. O., Mumma, A. O., \& Field-Juma, A. (1995). Governance of water resources in Kenya (Ecopolicy Series No. 8). Nairobi: Acts Press.

Weintraub, P. G. (2009). Physical control: an important tool in pest management programs. In I. Ishaaya, \& A. R. Horowitz (Eds.), Biorational control of arthropod pests (pp. 317-324). Springer, Netherlands. https://doi.org/10.1007/978-90-481-2316-2_12 
Weintraub, P. G., \& Berlinger, M. J. (2004). Physical control in greenhouse and field crops. In A. R. Horowitz, \& I. Ishaaya (Eds.), Insect pest management (pp. 301-318). Springer, Berlin. https://doi.org/10.1007/97 8-3-662-07913-3_12

Zeggaf, T. A., \& Filali, M. Y. (2010). Problems and prospects use efficiency of agricultural water in the Maghreb. In the State Water Resources in North Africa in 2009 UNESCO publication (pp. 203-217).

\section{Copyrights}

Copyright for this article is retained by the author(s), with first publication rights granted to the journal.

This is an open-access article distributed under the terms and conditions of the Creative Commons Attribution license (http://creativecommons.org/licenses/by/4.0/). 